\title{
Screening and Testing the Effect of Biocontrol Agents (Bacillus sp.) and Fusarium oxysporum f. sp. ciceri strains (Wilt) on Plant Defense Enzymes in Chickpea
}

\author{
Kiran K. Reddy ${ }^{*}$ and K. Annapurna \\ Division of Microbiology, IARI, New Delhi-110012, India \\ *Corresponding author
}

\begin{abstract}
A B S T R A C T
Keywords

Wilt, Days after germination (DAG), Chlorophyll

Article Info

Accepted:

22 July 2018

Available Online:

10 August 2018

Wilt (Fusarium oxysporum f. sp. ciceris) is considered as one of the major factors for low productivity of chickpea (Cicer arietinum L.). In order to address the problem, germinated seeds of 'Desi' chickpea cv. JG-62 were inoculated with a conidial suspension (root dip) of highly virulent Fusarium oxysporum f. sp. ciceris (Foc) race 4, three days after germination (DAG). The extent of disease suppression was studied with two bacterial biocontrol agents B-36 and MSUC-2. Out of seventeen bacterial isolated screened for antifungal activity, strain B-36 reported maximum inhibition zone of $15 \mathrm{~mm}$ with fungal strain 101, which has shown maximum virulence (55.6\% reduction in plant stand). Chlorophyll and nitrogen content has reduced by $25.2 \%$ and $66 \%$ respectively at 30 DAS in pathogen inoculated treatment. $\beta$ 1,3 glucanse, chitinase, phenylalanine ammonia lyase activities had 1.9, 2.02 and1.72fold increase respectively in B-36 treated seeds compared to pathogen only treated seeds. $16 \mathrm{~S}$ rDNA sequencing of both the bacterial cultures identified them as Bacillus subtilis (Acc No: KX 503819) and Bacillus sp (Acc No: KX 503820) respectively
\end{abstract}

\section{Introduction}

Chickpea (Cicer arietinum) is one of the most important food legumes grown worldwide, especially in dry areas of the Indian subcontinent (Saxena, 1990) and is one of the most important pulse crops cultivated in many countries of Asia and Africa. In addition to its importance as a food crop, it is valued for its beneficial effects in improving soil fertility and thus sustainability and profitability of production systems (Siva Ramakrishnan et al., 2002). Fusarium wilt caused by Fusarium oxysporum f. sp. ciceris is a major factor restraining chickpea production worldwide. The disease is widespread in chickpeagrowing areas of the world and is reported from at least 33 countries, causing 10-15\% annual losses. The use of resistant cultivars is one of the most practical and cost-effective strategies for managing Fusarium wilt, but deployment of resistant varieties has not been extensive because of undesirable agronomic characteristics. Moreover, the high pathogenic variability in $F$. oxysporum f. sp. ciceris may limit the effectiveness of resistance (Haware and Nene 1982). These races are differentiated based upon their wilting symptoms caused by 
them in the host plants. The most effective and practical method for management of the disease worldwide is the use of resistant cultivars (Jalali and Chand, 1992). However, the effectiveness of host resistance is curtailed by the occurrence of various pathogenic races. Seven Foc (Fusarium oxysporumf. sp. ciceri) races (0-6) have been identified (JiménezDíaz et al., 1993). Races 1-4 were first described in India (Haware and Nene, 1982). Later, race 0 was reported in California (USA), Israel, Lebanon, and races 1 and 6 were identified in California, Israel, Morocco and Spain. Race 5, the most virulent of the races occurring in Spain, also occurs in California (Halila and Strange, 1996). The first objective of this study is to isolate different strains of Fusarium oxysporum f. sp. ciceri and study their virulence under pot trials. The second objective of this study is to select the best antagonistic bacterial agent against the fungus and to study their interaction effect on the plant defense enzyme perturbations.

\section{Materials and Methods}

\section{Isolation of fungal strains}

Total six strains of Fusarium oxysporum f. sp. ciceri belonging to the race 4 were collected from different regions of Andhra Pradesh and Sick plot of IARI. Wilted chickpea plants were surface sterilized with $0.1 \% \mathrm{HgCl}_{2}$ for 1 min. and the associated fungus was isolated on potato dextrose agar (PDA) (potato200 g, dextrose $20 \mathrm{~g}$, agar $20 \mathrm{~g}$ and water $1 \mathrm{l}$ ) medium. Single spore culture of fungus was obtained by serial dilution method. The pure culture of the fungus was multiplied on autoclaved sorghum seeds in incubator at $28 \pm 1^{\circ} \mathrm{C}$ for 7 days (Fig. 2).

\section{Validation of collected fungal strains}

Fungal strains were validated for their identity of Fusarium genus by conforming under microscope (Carl Zeiss microscopy Inc. Axiocam 506 mono). Spore suspension in sterile milliQ water was prepared and observed for macro- and microconidia.

\section{Screening for best virulent fungal strain}

Desi chickpea variety JG-62 (Susceptible to fusarium wilt) along with cv. BG-212 (resistant to fusarium wilt) were used for screening. Seeds were surface sterilized in 0.1 $\% \mathrm{Hgcl}_{2}$ followed by two washes of $70 \%$ ethanol and seven washes of sterile water. Sterile pot culture mix $(2: 1: 1$ soil: sand: vermiculite) was used as base for filling in 4" plastic pots. Three seeds/pot were sown after germination. Different dose of inoculum was used ranging from 0 to $60 \mathrm{~g}$ inocula $/ \mathrm{kg}$ potting mix. Each gram of inoculum (on sorghum base) consisted of $2.37 \times 10^{7}$ conidia, as measured by Hemocytometer.

\section{Screening for best antagonistic bacterial agent}

Total seventeen bacterial isolates were screened on potato dextrose agar for the zone of inhibition. A stab of most virulent fungal culture (Foc str. 101) was used. A streak of bacterial cultures maintained on the slant were used. The plates were incubated for one week at $28 \pm 2{ }^{\circ} \mathrm{C}$

Pot experiment to unravel the tri-way communiqué vis-à-vis host plant, pathogen and antagonistic agent

A pot experiment was conducted with seven treatments (Table 2) in glasshouse at $28{ }^{\circ} \mathrm{C}$. Three sterilized seeds/pot were used. $20 \mathrm{~g}$ fungal inoculum (Foc str. 101) per $\mathrm{kg}$ of potting mix (2:1:1 soil: sand: vermiculite) was used, three days before sowing. Seeds were treated with Bacillus sp. cultures (B-36 and MSUC-2), which were grown in nutrient broth for $48 \mathrm{~h}$ at $37{ }^{\circ} \mathrm{C}$ in shaking incubator of 180rpm, till O.D of 0.8 was achieved. 
Observations like chlorophyll content and nitrogen $\%$ in shoot and defense related enzymes were measured at 30 DAS.

\section{Assay of enzyme activities}

Peroxidase activity was assayed spectrophotometrically (Hartee 1955). The reaction mixture has $1.5 \mathrm{ml}$ of $0.05 \mathrm{M}$ pyrogallol, $0.5 \mathrm{ml}$ of enzyme extract and 0.5 $\mathrm{ml}$ of $1 \% \mathrm{H}_{2} \mathrm{O}_{2}$. The reaction mixture was incubated at room temperature.

The change in absorbance at $420 \mathrm{~nm}$ was recorded at $30 \mathrm{sec}$ intervals for $3 \mathrm{~min}$ and the boiled enzyme preparation served as blank. Phenylalanine ammonia lyase (PAL) assay was done as per the method described by Ross and Sederoff (1992).

The assay mixture containing $1 \mathrm{ml}$ of enzyme, $5 \mathrm{ml}$ of $50 \mathrm{mM}$ Tris $\mathrm{HCl}(\mathrm{pH} \mathrm{8.8)}$ and $6 \mathrm{ml}$ of $1 \mathrm{mM}$ L-phenylalanine was incubated for 60 min. The reaction was arrested by adding $2 \mathrm{~N}$ $\mathrm{HCl}$. Later $0.15 \mathrm{ml}$ of toluene was added, vortexed for $30 \mathrm{sec}$, centrifuged $(1000 \mathrm{rpm}, 5$ min) and toluene fraction containing transcinnamic acid was separated. The toluene phase was measured at $290 \mathrm{~nm}$ against the blank of toluene. A standard curve was drawn with graded amounts of cinnamic acid in toluene

$\beta$-1, 3-glucanaseenzyme activity was colorimetrically assayed (Pan et al., 1991). Crude enzyme extract of $6.25 \mathrm{ml}$ was added to $6.25 \mathrm{ml}$ of $4 \%$ laminarin and incubated at $40^{\circ} \mathrm{C}$ for $10 \mathrm{~min}$. The reaction was stopped by adding $3.75 \mathrm{ml}$ of dinitrosalicylic acid (DNS) and heated for 5 min on boiling water bath (DNS prepared by adding $300 \mathrm{ml}$ of $4.5 \%$ $\mathrm{NaOH}$ to $880 \mathrm{ml}$ containing $8.8 \mathrm{~g}$ of DNS and $22.5 \mathrm{~g}$ potassium sodium tartarate). The resulting coloured solutions were diluted with distilled water, vortexed and the absorbance was read at $500 \mathrm{~nm}$. The crude extract preparation mixed with laminar in at zero-time incubation served as blank. The colorimetric assay of chitinase was carried out as per Boller and Mauch (1988). Reagents used consist of colloidal chitin, snail gut enzyme, dimethyl amino benzaldehyde (DMAB) and buffer. Chlorophyll content of the shoot was estimated by the technique of Arnon (1949) and nitrogen content of the shoot was estimated by the technique of Lindner (1944).

\section{Results and Discussion}

\section{Anti-fungal activity of isolates}

17 bacterial isolates were used from different sources to test their antifungal activity against Fusarium oxysporum f. sp. ciceri isolate 101 (Race 4). Out of 17, only 10 (59\%) showed inhibition, rest 7 (41\%) didn't exhibit inhibition zones (Table 1). Only 2 (11.7\%) bacterial strains B-36 and MSUC-2 exhibited and inhibition zone above $1 \mathrm{~cm}$ and B-36 topped the list with maximum inhibition zone of $1.5 \mathrm{~cm}$ (Fig. 1). 7 isolates (41\%)showed zone of inhibition $\geq 0.5 \mathrm{~cm}$.

Several Bacillus spp. are known to suppress the soil-borne pathogens by various mechanisms viz., production of a wide range of broad spectrum antifungal metabolites, mycoparasitism, competition with the pathogen for nutrient and for occupation of infection court, induced resistance, production of protease and fungal cell wall degrading enzymes (Perello et al., 2003).

\section{Selection of virulent fungal strain}

Isolation of different Fusarium isolates (6 no.) from chickpea growing regions of India was done. The isolation was done from infected chickpea roots, following washing and surface sterilization on PDA media. The isolates were confirmed as Fusarium sps. based on observations of micro and macro-conidia 
under $40 \mathrm{X}$ microscopy (CarlZeiss) (Fig. 4). These isolates were tested for disease incidence and severity \% in glass house. This is done to select the most virulent strain and also to standardize the inoculums dose. str. 101 has shown strong virulence, followed by str. 101> str. $105>$ str. $21>$ str. 52> str. 33= str. 38 in decreasing order of virulence.

Effect of different fungal strains on Germination \% and plant stand \% and optimization of inocula dosage

Out of the six fungal strains, strain 101 exhibited $10 \%$ reduction in germination\% at $4 \mathrm{DAS}$ and $54.6 \%$ reduction in plant stand at 30DAS (Table 2).

Inocula at high dosages $(40 \mathrm{~g} / \mathrm{kg}$ and $60 \mathrm{~g} / \mathrm{kg}$ planting media) completely inhibited the chickpea growth. So $20 \mathrm{~g} / \mathrm{kg}$ was selected was considered as optimum dosage for conduct of experiments with Fusarium oxysporum f. sp. ciceri strain 101 (Fig. 3).
Evaluating the effect of biocontrol agents on disease control parameters

Pot experiment was conducted with sterilized potting mixture (soil + vermiculite) and inoculated with fungal pathogen (one week before sowing). 4 seeds/pot are sown. Chlorophyll content was found to be highest when chemical seed treatment was done $\left(\mathrm{T}_{6}\right.$ $8.99 \mathrm{mg} / \mathrm{g} \mathrm{FW}$ ) followed by Mesorhizobium $s p$. treated seed $\left(\mathrm{T}_{2}-7.58 \mathrm{mg} / \mathrm{g} \mathrm{FW}\right)$. Lowest chlorophyll content was found with MSUC-2 treated seed $\left(\mathrm{T}_{5}-2.75 \mathrm{mg} / \mathrm{g} \mathrm{FW}\right)$. B-36 treated seed reported $29.9 \%$ more chlorophyll content than pathogen only treated seeds (Fig. 5). Nitrogen content was found to be highest in $\mathrm{T}_{1}$ $(1.26 \mathrm{mg} / \mathrm{g} \mathrm{FW})$ and lowest in $\mathrm{T}_{3}(0.42 \mathrm{~m} / \mathrm{g}$ FW). B-36 treated seed has nitrogen content at par with $\mathrm{T}_{1}$ (Fig. 6). Similar results were reported on fusarium wilt of lentil (Ahmed D et al., 2017). The levels of different enzymes like $\beta$-1,3-glucanase, chitinase, peroxidase and phenylalanine ammonia lyase were analysed in root tissues at $30 \mathrm{DAS}$ after biocontrol and pathogen inoculation.

Table.1 Zone of inhibition of different bacterial strains against

Fusarium oxysporum $f$. sp. ciceri isolate 101

\begin{tabular}{|l|l|l|}
\hline S. No & Culture No. & Zone of Inhibition (cm) \\
\hline $\mathbf{1}$ & L-23 & No inhibition \\
\hline $\mathbf{2}$ & B-16 & No inhibition \\
\hline $\mathbf{3}$ & B-26 & No inhibition \\
\hline $\mathbf{4}$ & B-29 & No inhibition \\
\hline $\mathbf{5}$ & B-36 & 1.5 \\
\hline $\mathbf{6}$ & HKA-15 & 0.1 \\
\hline $\mathbf{7}$ & Wi-21 & 0.5 \\
\hline $\mathbf{8}$ & MSUC-2 & 1.1 \\
\hline $\mathbf{9}$ & Wi-2 & 0.3 \\
\hline $\mathbf{1 0}$ & HKA-121 & 0.8 \\
\hline $\mathbf{1 1}$ & B-33 & No inhibition \\
\hline $\mathbf{1 2}$ & F1-B & No inhibition \\
\hline $\mathbf{1 3}$ & Wi-9 & 0.7 \\
\hline $\mathbf{1 4}$ & B-48 & No inhibition \\
\hline $\mathbf{1 5}$ & B-50 & 0.4 \\
\hline $\mathbf{1 6}$ & L-18 & 0.9 \\
\hline $\mathbf{1 7}$ & L-8 & 0.8 \\
\hline
\end{tabular}


Table.2 Effect of Fusarium oxysporum f. sp. ciceri race 4 strains on germination and plant stand

\begin{tabular}{|l|l|l|l|}
$\begin{array}{l}\text { Strain } \\
\text { Name }\end{array}$ & Source & $\begin{array}{l}\text { Germination } \\
(\%) \text { at 4 DAS }\end{array}$ & $\begin{array}{l}\text { Plant stand (\%) } \\
\text { at 30 DAS }\end{array}$ \\
\hline str. 101 & Div. Of Plant Pathology & 90 & 44.4 \\
\hline str. 105 & Isolated from IARI soil (Sick plot) & 100 & 66.6 \\
\hline str. 52 & Isolated from IARI soil (Sick Plot) & 100 & 77.7 \\
\hline str. 21 & Chickpea grown region of A.P (Kurnool) & 100 & 66.6 \\
\hline str.33 & Chickpea grown region of A.P(Gadwal) & 100 & 100 \\
\hline str. 38 & Chickpea grown region of A.P (Maldakal) & 100 & 100 \\
\hline
\end{tabular}

Table.3 Effect of different treatments on enzyme activities in root at 30 DAS

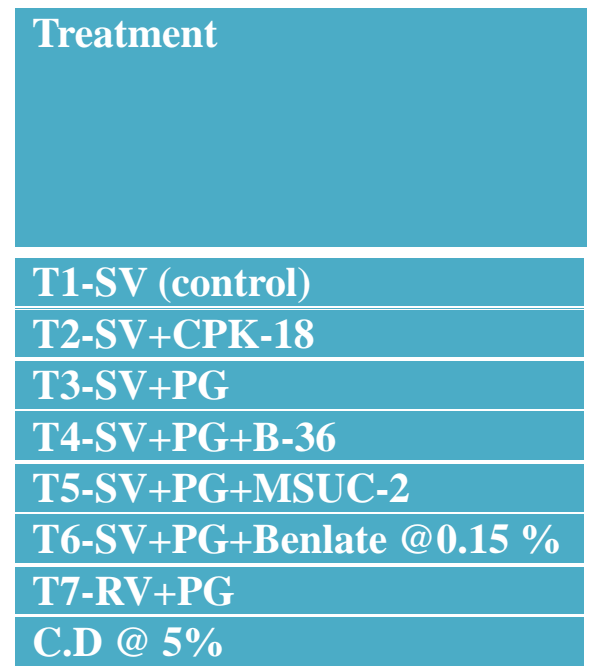

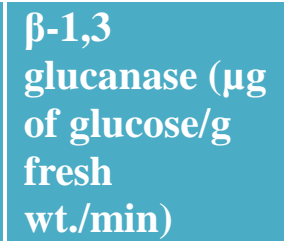

4.13

\begin{tabular}{|r|}
\hline 4.04 \\
\hline 6.91 \\
\hline 13.19 \\
\hline 8.68 \\
\hline 6.75 \\
\hline 18.45 \\
\hline 0.92 \\
\hline
\end{tabular}

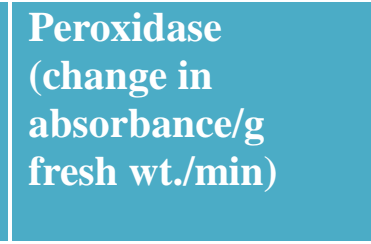

0.79
0.69
2.97
1.32
1.41
0.26
0.18
0.28

Chitinase ( $\mu \mathrm{g}$
of glucose/g
fresh
wt./min)

Phenylalanine Ammonia lyase (n.mol of transcinnamic acid/g fresh $\mathrm{wt} / \mathrm{min}$ )

\begin{tabular}{|r|r|}
\hline 7.32 & 11.81 \\
\hline 3.71 & 11.48 \\
\hline 8.98 & 17.68 \\
\hline 18.16 & 30.42 \\
\hline 11.59 & 21.45 \\
\hline 3.9 & 16.08 \\
\hline 13.50 & 26.14 \\
\hline 1.24 & 2.01 \\
\hline
\end{tabular}

SV-Susceptible var. (JG-62); RV-Resistant variety (BG-212); Fungicide-Benlate at $0.15 \%$; PG-Pathogen; BCABiocontrol agent

Fig.1 Exhibits A, B, C, D showing Inhibition zones of various isolates

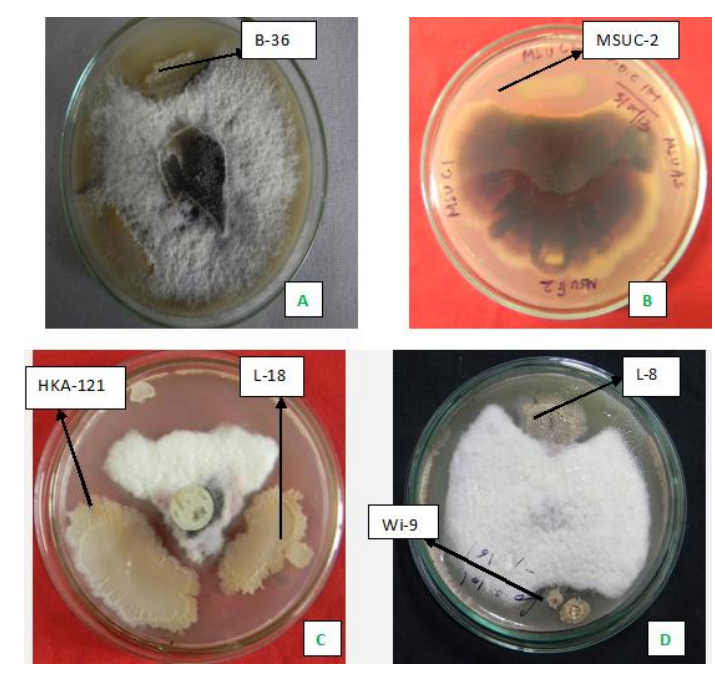


Fig.2 Fusarium fungus is grown on autoclave sorghum seeds. Spore count ranged between 2-6 x $10^{7}$ spores/gm of sorghum seeds

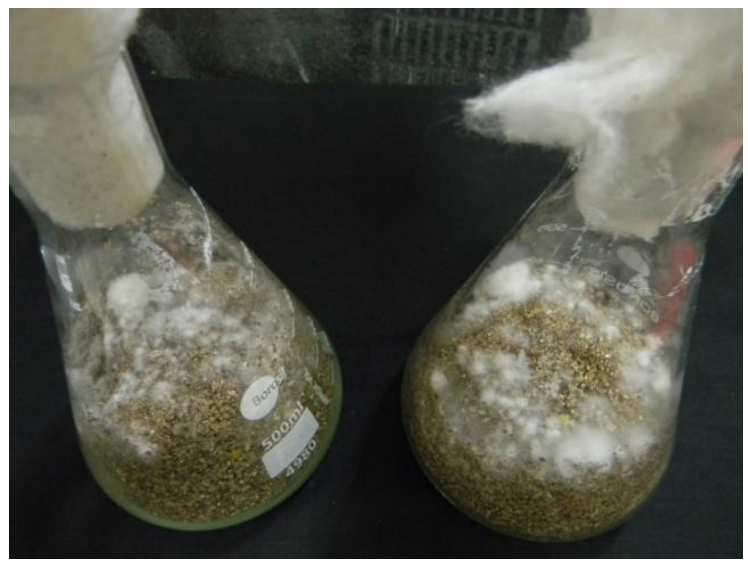

Fig.3 Effect of variable inocula dosage of Fusarium oxysporum f. sp. ciceri strain 101 on growth of chickpea. A) Only Susceptible variety JG-62 without inocula. B, C, D represent 20, 40, 60 g of inocula per $\mathrm{kg}$ of growth/planting media respectively

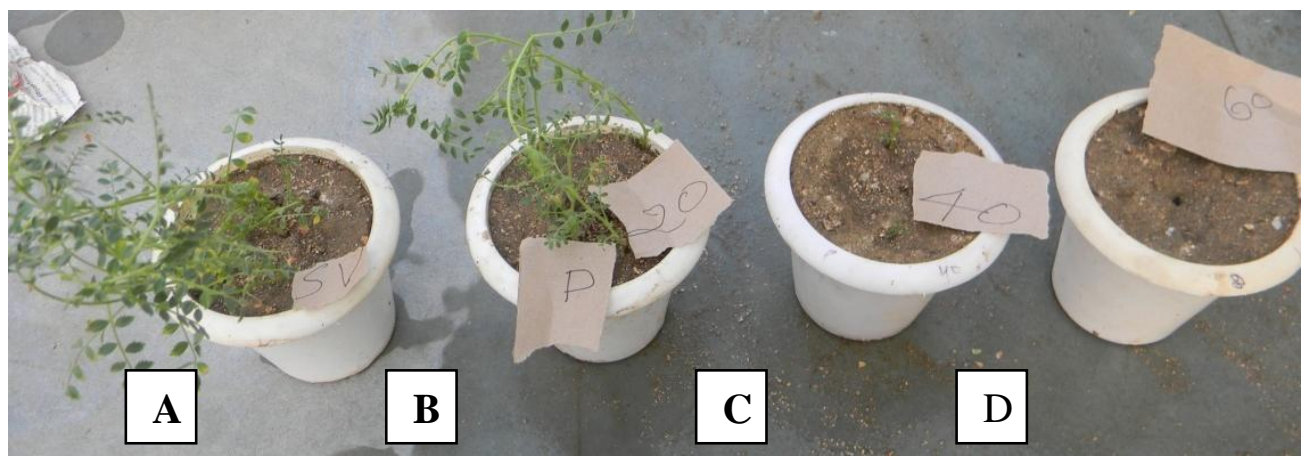

Fig.4 Micro- and macroconidia of different Fusarium strains observed under $40 \mathrm{X}$ (Carl Zeiss microscopy Inc. Axiocam 506 mono) A) str. 101 B) str. 105 C) str. 52 D) str. 21 E) Str.33 F) str.
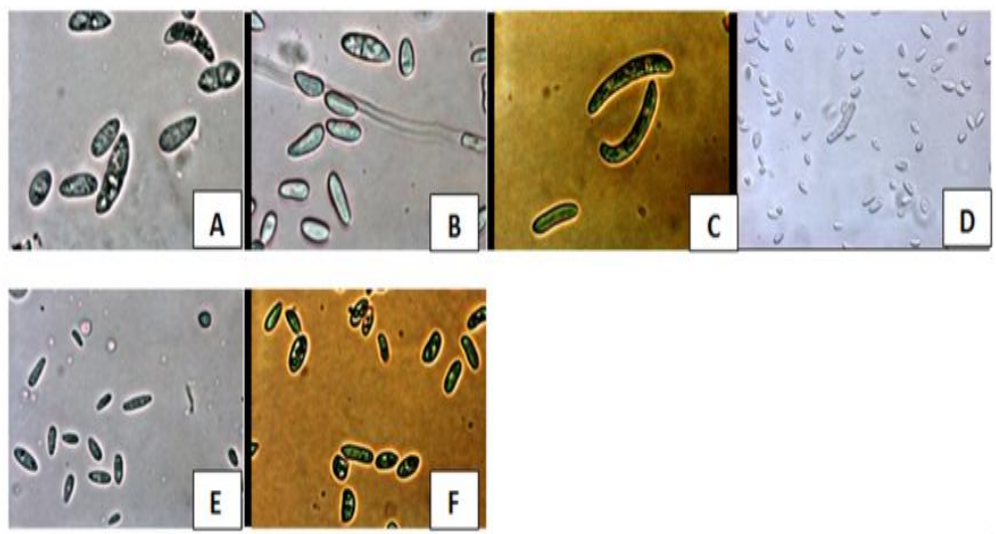
Fig.5 Chlorophyll content of shoot at 30 DAS

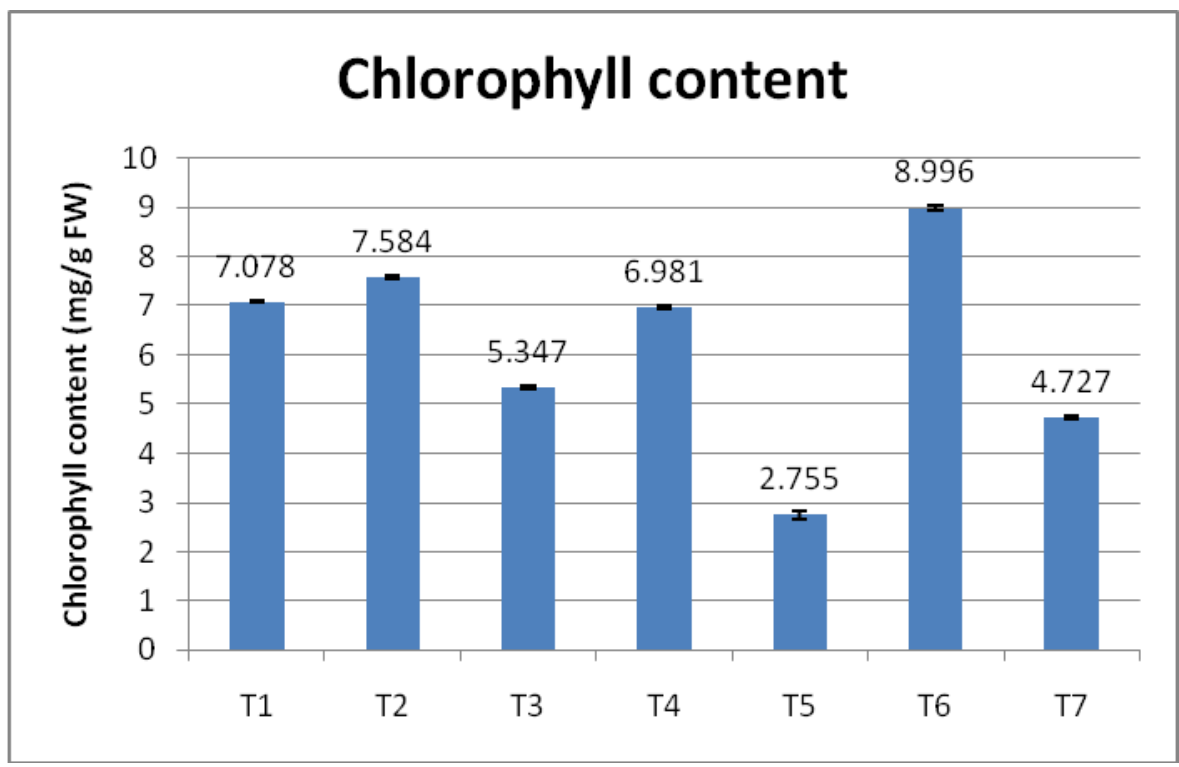

Fig.6 Nitrogen content of shoot at 30DAS

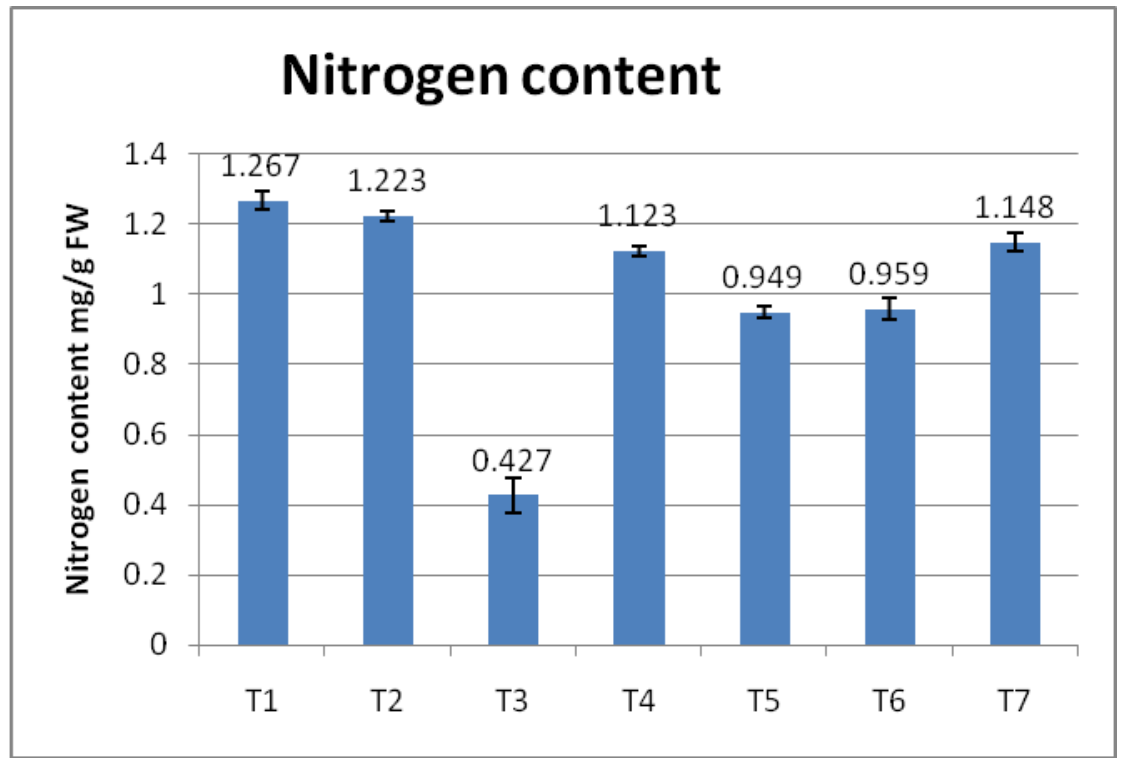

All the enzymes except peroxidase was found to be up surged by about $72-102 \%$ in B-36 treated seed compared to pathogen only treated seed. In $\mathrm{T}_{7}$ treatment, there is a 1.9-3.1 fold increase in enzyme activities (Table 3 ).

This may to due to early triggering of the phenylpropanoid pathway. Similar results were reported in Rhizobium treated chickpea seed (Arfaoui et al., 2005). Das et al., (2003) has stressed that peroxidase enzyme is a key enzyme of the phenyl propanoid pathway, activated in response to pathogen infection. Changes in the activity of phenoloxidizing enzymes including peroxidise, plays a role in the regulation of metabolic pathways in diseased or injured tissues (Mehrotra and Aggarwal, 2003). 
Fusarium oxysporum f. sp. ciceri race 4 strains vary widely with respect to their virulence abilities. Although chemical control and use of resistant varieties found to be effective in controlling the wilt in our experiment, they cause environmental damage and genetic resistance breakdown respectively. So, Biocontrol of wilt by seed treatment with B-36 strain in susceptible cultivars like JG-62 appears to be cheap and effective option.

\section{Acknowledgment}

The Author is thankful to DST for providing INSPIRE fellowship during the course of Ph.D work

\section{References}

Ahmed, D., and Shahab, S. 201. Effect of different inoculum levels of' Fusarium solani'(Mart.) sacc on plant growth, biochemical and nutrient parameters of lentil ('Lens culinaris' Medik.). International Journal of Agriculture, Environment and Biotechnology, 10(2), 239.

Arfaoui, A., Sifi, B., El Hassni, M., El Hadrami, I., Boudabbous, A., and Chérif, M. 2005. Biochemical analysis of chickpea protection against Fusarium wilt afforded by two Rhizobium isolates. Plant Pathology Journal, 4(1), 35-42

Arnon D.I., 1949. Copper enzymes in isolated chloroplasts. Polyphenol oxidase in Beta vulgaris. Plant Physiology 24: 115

Boller T, Mauch F. 1988. Colorimetric assay for chitinase. Meth Enzymol 161: 430435.

Das S., Aggarwal R., Singh D.V. 2003. Differential induction of defense related enzymes involved in lignin biosynthesis in wheat in response to spot bloth infection. Indian Phytopathol.56 (2): 129-133.

Halila MH, Strange RN, 1996. Identification of the causal agent of wilt of chickpea in Tunisia as Fusarium oxysporum f. sp. ciceris race. Phytopathologia Mediterranea 35, 67-74.

Hartee EF. 1955. Haematin compounds. In: Peach K, Tracy M, editors. Modern methods of plant analysis. New York: Springer-Verlag. pp 197-245.

Haware MP, Nene YL, 1982. Races of Fusarium oxysporum f. sp. ciceris. Plant Disease 66, 809-10.

Jalali BL, Chand H, 1992. Chickpea wilt. In: Singh US, Mukhopadhayay AN, Kumar J, Chambe HS, eds. Plant Diseases of Cereals and Pulses. Englewood Cliffs, NJ: Prentice Hall, 429-44.

Jiménez-Díaz RM, Alcalá-Jiménez AR, Hervás A, Trapero-Casas JL, 1993. Pathogenic variability and host resistance in the Fusarium oxysporum $\mathrm{f}$. sp. ciceris/Cicer arietinum pathosystem. In: Arseniuk E, Goral T, eds. Fusarium Mycotoxins, Taxonomy, Pathogenicity and Host Resistance. Proceedings of the 3rd European Seminar. Radzikov, Poland: Plant Breeding and Acclimatization Institute, 87-94.

Lindner R.C., 1944. Rapid analytical method for some of the more common inorganic constituents of plant tissues. Plant Disease 66: 9-14.

Mehrotra R.S., Aggarwal R.S. 2003. Plant Pathology. Tata McGraw Hill Publishing Company Limited, New Delhi, 846 pp

Pan SQ, Ye XS, Kuc J. 1991. Association of $\beta$-1, 3-glucanase activity and isoform pattern with systemic resistance to blue mold in tobacco induced by stem injection with Peronospora tabacina or leaf inoculation with tobacco mosaic virus. PhysiolMolec Plant Pathol 39:2539. 
Perello A., Monaco C., Simon M.R., Sisterna M., Dalbello G. 2003. Biocontrol efficacy of Trichoderma isolates for tar spot of wheat in Argentina. Crop Prot. 22 (7): 1099-1106

Ross WW, Sederoff RR. 1992. Phenylalanine ammonia lyase from loblolly Pine: Purification of the enzyme and isolation of complementary DNA clone. Plant Physiol 98: 380-386

Saxena MC, 1990. Problems and potential of chickpea production in the nineties. In: Chickpea in the Nineties. Proceedings of the Second International Workshop on Chickpea Improvement, 4-8
December 1989. Patancheru, India: ICRISAT, 13-27

Singh, K. B. and Dahiya, B. S., Breeding for wilt resistance in chickpea. In Symposium on Problem and Breeding for Wilt Resistance in Bengal Gram, IARI, New Delhi, September 1973, pp. 13-14

Sivaramakrishnan, S., Kannan, S. and Singh, S. D., Genetic variability of Fusarium wilt pathogen isolates of chickpea (Cicer arietinum L.) assessed by molecular markers. Mycopathologia, 2002, 155, 171-178

\section{How to cite this article:}

Kiran K. Reddy and Annapurna, K. 2018. Screening and Testing the Effect of Biocontrol Agents (Bacillus sp.) and Fusarium oxysporum f. sp. ciceri strains (Wilt) on Plant Defense Enzymes in Chickpea. Int.J.Curr.Microbiol.App.Sci. 7(08): 4049-4057.

doi: https://doi.org/10.20546/ijcmas.2018.708.420 